\title{
TRABALHO, SINDICATOS E MOVIMENTOS SOCIAIS NOS ESTADOS UNIDOS HOJE: UMA ENTREVISTA COM RUTH MILKMAN
}

Ruth Milkman ${ }^{\mathrm{a}}$

aé professora emérita da City University of New York. Nova York, NY, Estados Unidos da América.

Orcid: 0000-0001-8859-4541

http://dx.doi.org/10.1590/0102-317327/104

Desde o final dos anos 1980, o nome de Ruth Milkman, professora emérita da City University of New York (CUNY), tem sido uma presença frequente na literatura e nos debates sobre estudos do trabalho pelo mundo. Pode-se dizer que, em sentido amplo, isso se deve ao fato de ela ser uma meticulosa e engajada analista do mundo do trabalho, bem como de suas organizações. O que se percebe, observando sua trajetória, é a combinação equilibrada de rigor científico e engajamento público.

Essa articulação está explicitada também em seus engajamentos institucionais. Milkman dirigiu centros como o Institute for Research on Labor and Employment (IRLE), da University of California at Los Angeles (UCLA), entre 2001-2008 - quando, inclusive, esteve à frente da luta contra os cortes aos programas de pesquisa e educação sobre trabalho e trabalhadores, desses institutos, na Universidade da Califórnia em Los Angeles e Berkeley, propostos pelo então governador Arnold Schwarzenegger -, e a área de pesquisa do Joseph S. Murphy Institute for Workers Education and Labor Studies, da CUNY, nos quais o contato direto e a formação com os movimentos de trabalhadores/as estiveram fortemente presentes. 
Outra marca destacada de seus investimentos, em que o desenvolvimento dos processos históricos e sociais ganham espaço relevante, tem sido o olhar dedicado às formas de vida, organização e protesto de grupos muitas vezes marginalizados nas pesquisas acadêmicas e nas formas tradicionais de organização. Seus estudos, por exemplo, sobre mulheres e imigrantes no mundo do trabalho tiveram grande impacto e orientaram um conjunto expressivo de outras pesquisas e reflexões sobre esses temas. Isso sem se descuidar de observar também, em outro flanco, a importância passada e presente dos sindicatos, ainda que apresentando seus limites e os desafios por eles enfrentados. (Milkman, 1987; 1997; 2000; 2006; 2016).

Mais recentemente - e seu discurso como presidente da American Sociological Association (ASA), para a gestão de 2016, mostra isso - tem contribuído na reflexão sobre os movimentos da chamada "geração milênio" (os millennials), 318 principalmente as dinâmicas do Occupy Wall Street e do Black Lives Matter, sempre atenta ao olhar da interseccionalidade entre classe, raça e gênero. (Milkman, 2014; 2017).

Ao longo de todo seu percurso acadêmico, Ruth manteve relação com diferentes centros universitários e entidades no Brasil. Por exemplo, nos anos 1990, foi professora visitante da Universidade de São Paulo (USP), em 2011 proferiu conferência em seminário em homenagem a Elisabeth Souza-Lobo, na mesma universidade, tratando do tema gênero e trabalho na crise econômica. Mais recentemente, em 2017, fez a conferência de abertura do congresso da Associação Brasileira de Estudos do Trabalho (Abet), analisando os impactos das políticas de Donald Trump no mundo do trabalho estadunidense.

Na entrevista a seguir, realizada por Marco Aurélio Santana, em julho de 2018, Ruth reflete sobre a atual situação do trabalho e dos/as trabalhadores/as nos Estados Unidos, nos auxiliando a pensar acerca dos velhos e dos 
novos desafios de organização e mobilização que estão postos para os sindicatos e os movimentos sociais, bem como para suas possibilidades - ainda que com tensionamentos de convergência. Mesmo que centrada na experiência estadunidense, a entrevista fornece elementos interessantes que podem lançar luz, em termos gerais, sobre esse complexo momento atravessado pelas forças sociais do trabalho ao redor do mundo.

SANTANA - What is your view about the labor organizations' action today?

MILKMAN - Traditional labor unions have lost power and influence almost everywhere since the neoliberal turn of the 1970s. The USA is a case in point: union density is now lower than any time since the New Deal reforms of the 1930s, with only 6.5 percent of private-sector workers unionized in 2017. One cause of the decline is outsourcing, as capital mobility accelerated starting in the 1970s. But even in sectors where the work is place-bound - building construction, transportation, health care and other service industries - there has been a sharp decline in union density and union power. Unions will not disappear entirely - as long as there is capitalism, workers will seek to act collectively - but they will have to adapt to the new order.

The type of collective bargaining that flourished in the USA in the post-World War II era is no longer viable. Employers have succeeded in defanging the laws governing labor relations, and undermining the effectiveness of enforcement agencies. For example, they have increasingly taken advantage of the option, legal since the late 1930s but seldom practiced before the 1970s, of hiring "permanent replacements" for workers who go on strike for economic gains; as a result, the frequency of strikes has declined dramatically. With the help of professional anti-union consultants, employers have also learned to manipulate the law 
to maximize bureaucratic delays in union organizing campaigns, and then to use that time to instill fear in workers that unionization will have negative consequences. A growing number of companies have also broken the law outright. The prevalence of employers' Unfair Labor Practices under the 1935 National Labor Relations Act, such as firing workers for supporting unions, or threatening to close a plant if workers unionize (both of which are illegal), has skyrocketed since the 1970s. Even when employers are found to be in violation of the law (which is often a lengthy process), the penalties are so small that employers view them as a "cost of doing business."

These practices are commonplace among private-sector employers. Until this year, public sector unionism was far more widespread (about a third of all public-sector workers are unionized), and more stable than its private sector counterpart, since employer opposition to unions represen320 ting workers in government agencies is minimal. However, public-sector unions are now under attack as well by right-wing organizations funded by the Koch brothers and other wealthy conservatives. Those groups funded successful campaigns to change state laws to weaken public-sector unions, most famously in Wisconsin in 2011, and they also have facilitated lawsuits to challenge public-sector labor laws in the federal courts. Their big win was the decision by the U.S. Supreme Court in the Janus case this spring, which will lead to dramatic declines in public-sector union membership and financial resources. Although unions have tried to prepare for that decision, which they expected ever since Trump was elected, the impact is likely to be devastating.

SANTANA - Considering the neoliberal hegemony what can we expect as possibilities of labor's resistance?

MILKMAN - One possibility that some labor activists have explored is to develop new forms of labor organization. The 
"alt-labor" [alternative labor] community-based organizations - there are over 200 in the USA today - also known as "worker centers," are the most promising model. These organizations operate outside the established framework of collective bargaining. They are basically NGOs [non-governmental organizations] that organize and advocate for low wage workers, most of them immigrants, typically staffed by progressive lawyers or other professionals. The worker centers "name and shame" employers who violate existing employment standards, for example paying less than the minimum wage, and they also initiate legal action to remedy such violations. Another part of the worker centers' agenda is to educate workers about their rights and conduct leadership development trainings to help empower them to organize autonomously.

These alt-labor groups have had a big impact at the discursive level, but they are mostly quite small and dependent on funding from philanthropic foundations (for example, the Ford Foundation), so their reach is limited. And while they can bring workers up to the legal minimum standards, they do not have mechanisms to win further improvements of the sort unions have historically secured through collective bargaining. The traditional unions were skeptical about the alt-labor groups when they first emerged in the 1990s, but more recently they have become highly supportive, and some have developed formal partnerships with worker centers.

Another promising recent development has been the growth of unionism among college-educated young professionals in the "Millennial" generation (those born after 1980). Unions have expanded among adjunct faculty and graduate student workers, as well as in journalism, building on this generation's social media skills as well as their left-leaning, pro-union ideological outlook. Like alt-labor, these organizing efforts have been small in scale, but they 
do suggest the possibility of union revival in certain niches of the labor market.

The teachers' strikes in West Virginia and other states this spring were also fueled in part by this dynamic. The West Virginia teachers began their organization by setting up a private Facebook group; the same was true in Oklahoma. And Millennials have also pressured high-tech companies like Google and Amazon to discontinue their collaboration with ICE (the Immigration and Customs Enforcement agency that has ramped up deportations and separated immigrant families under Trump) as well as the police. Traditional unions have a history of being isolated socially and politically, but since the 2008 economic crisis they have begun to build ties to social movements (also Millennialled) like Occupy Wall Street (OWS) and Black Lives Matter (BLM). Organized labor also has actively supported the immigrant rights movement.

SANTANA - In which ways the unions in the U.S. are dealing with class, race and gender intersectionality?

MILKMAN - What remains of union membership is now about half female, and African Americans are overrepresented. That is mostly due to the fact that both women and African Americans are employed in vast numbers in the public sector. Union leaders have become somewhat more oriented to intersectionality in the $21^{\text {st }}$ century than in the past, but the main source of input on these issues is that Millennial generation I already mentioned - young activists are deeply committed to the politics of intersectionality and often raise race and gender concerns, as well as LGBTQ issues, in their unions. Intersectionality was at the core of Black Lives Matter and also the campaigns of the "Dreamers" (immigrant youth brought to the U.S. as children who won "deferred action for childhood arrivals" - DACA - under Obama). The "Me Too" movement challenging sexual 
assault (especially its campus-based youth wing), similarly, understands gender, race and class oppression as inextricably interrelated. Unions are more old-fashioned in this respect, mostly because their membership skews older. But awareness of these issues is much greater today than in the 1960s and 1970s.

SANTANA - The immigration issue has been for a long time an ever present debate within the U.S. society and politics. Comparing its past and present how has developed the situation of immigrant labor in the U.S. ?

MILKMAN - This was an area of extensive labor union activity in the 1990s and 2000s. Labor migration to the USA surged after U.S. immigration law changed in 1965, and immigrants soon replaced U.S.-born workers in many urban occupations that had become less desirable as a result of neoliberal restructuring and de-unionization. By the 1990s, unauthorized immigrants, as well as those with legal status, were the predominant demographic group in many occupations at the bottom of the labor market in cities like Los Angeles, Chicago, and New York. Examples include domestic work, restaurants, gardening and landscaping, building services, taxi and truck driving, and residential construction.

Alongside the worker centers I mentioned already, which focused mainly on organizing low-wage immigrants in such occupations, there were unionization drives like the Service Employees International Union (SEIU)'s "Justice for Janitors" campaign, which successfully recruited thousands of poorly paid office cleaners, most of them Latino immigrants, starting in the 1980s. Similarly, unions in the hotel industry and in residential construction actively organized low-wage immigrants, including the undocumented, in this period.

The AFL-CIO [American Federation of Labor and Congress of Industrial Organizations] had supported restrictive immigration policies for decades but, as a result of these 
organizing developments, reversed its position on immigration in 2000, and became an important ally of the immigrant rights movement. Recently, however, with both unions and immigrants under severe attack from Trump and his allies, these efforts have been replaced by more defensive struggles. Unions have advocated for preserving DACA [Deferred Action for Childhood Arrivals] and a path to legalization for the undocumented immigrant Dreamers who were brought to the USA as children, and also have opposed the Trump administration's effort to dismantle Temporary Protected Status.

SANTANA - Comparing past and present how gender issues have been challenging the unions and social movements?

MILKMAN - Organized labor, like the labor market, is highly segregated by gender. So, for example, unions representing the building trades are nearly $100 \%$ male, and they are not addressing gender issues in any significant way. At 324 the other end of the spectrum, healthcare unions skew heavily female, and have been much more engaged with issues like gender pay equity, as well as paid leave for illness, parental leave, and more recently, sexual harassment. The U.S. does have a law banning sex discrimination in pay, but only a few states and cities mandate paid sick leave or paid family leave. Organized labor was a major supporter of those state and local paid leave laws. More recently, many of the more female-dominated unions have become engaged in the "Me Too" movement. So things have moved forward significantly relative to the past, but progress is uneven across a highly decentralized labor movement, in which many individual unions remain male-dominated both in membership and leadership and in regard to the issues they engage.

SANTANA - In June of this year, the Supreme Court ruled on Janus vs. American Federation of State, County and Municipal Employees (AFSCME), Council 31, as you mentioned earlier, preventing public 
sector unions to collect fees from nonunion workers for the service of collective bargaining. Could you give us a brief historical perspective on that process? What is really at stake here? How it will effectively impact the unions?

MILKMAN - This will have a major impact. Public sector union density has been stable since the 1970s, even as private sector unionism has collapsed. That's why the rightwing groups who financed the Janus lawsuit (and a similar case, Friedrichs, two years earlier) are so focused on the agency fee issues. Unions often offer large financial support to Democratic Party political candidates and this will make it much more difficult for them to do so, since it will reduce their treasuries greatly. Public-sector unions had a lot of time to prepare for Janus, and many have been reaching out to the workers they represent, trying to educate them about why it is in their interest to become union members if they are now only fee-payers, or for those who are already union members, to continue in that status. But the same right-wing groups that brought the Janus case to the court are now busily reaching out to those workers to make sure they know that they will continue to receive the same pay and benefits even if they stop paying fees or dues, and given the economic stress so many workers face, many are likely to do so. We know from the experience in Wisconsin, where public sector membership dropped sharply after Republican governor Scott Walker signed a similar law in that state immediately after he was elected in 2010 , that the impact is likely to be large.

SANTANA - The recent teachers' strikes swept important states in the country. How can we understand that movement?

MILKMAN - This was a vitally important set of strikes, a very effective challenge to austerity policies, which led to dramatic cuts in state support for public schools, especially in "Red" States (the popular term in the U.S. for states in which 
Republicans are politically dominant). And no one predicted these militant teacher strikes. As I already mentioned, this movement was led by Millennial-generation teachers using Facebook and other social media to organize. And that the strikers demanded not only higher pay for themselves but also more money for their schools and the students was crucial. About $30 \%$ of all U.S. union members are in the education sector, and so this is definitely a movement that matters. But there is another more sobering aspect to the story, which is that in this case the employers - school districts - actually supported the strikers and their demands. They too wanted more funding for the schools. So workers did not risk getting fired or "permanently replaced" for striking as would be the case in most other sectors of the economy.

SANTANA - Is it already possible to talk about either a union or a grassroots upsurge in the U.S. ?

326 MILKMAN - I don't think so. It's true that public attitudes toward unions have become more positive in recent years, perhaps reflecting growing awareness of skyrocketing inequality and of the unique role of unions in fighting it. But in terms of sheer power, employers hold most of the cards to a greater degree than any time since the early 1930s. That was already true before Donald Trump became the nation's president, and now his administration's policies are further enhancing business power and eviscerating workers' rights.

Apart from the Red states' teacher strikes this year, union strength is mostly limited to large cities in "Blue" states (Democratic Party dominated) - places like New York, Chicago, San Francisco, Los Angeles, and Seattle. In those settings, labor has more leverage politically and it's harder for employers to go on the offensive against them. Some commentators call this "fortress unionism" - organized labor is confined to a few fortress sites and virtually absent elsewhere, at least in the private sector. 
SANTANA - Is it possible to say that movements such as Occupy Wall Street and Black Lives Matter had some influence upon the unions? MILKMAN - In the late 20th century, unions became more and more politically isolated, but that has begun to change. Starting in the late $1990 \mathrm{~s}$, they began to move to the Left, and build alliances with other social movements. For example, unions had a large presence at the 1999 demonstrations against the World Trade Organization in Seattle, and a few years later the AFL-CIO joined the opposition to the U.S. invasion of Iraq. More recently, organized labor spoke out in support of Occupy Wall Street and Black Lives Matter. But union leaders did not anticipate the emergence of these movements; they were basically followers rather than leaders. On the other hand, those movements did have some impact on rank-and-file union members, energizing unions with new leadership and new ideas. Immigrant union activists have also contributed to this revitalization.

SANTANA - Amidst so many changes and crisis which would be a possible future you could foresee for the unions?

MILKMAN - I have learned the hard way that predicting the future is not something I am good at, so I'll pass on this one!

\section{Bibliografia}

Milkman, Ruth. Gender at work: the dynamics of job segregation by sex during

World War II Champaign. Urbana: University of Illinois Press, 1987. . Farewell to the factory: auto workers in the late twentieth century.

Berkeley: University of California Press, 1997.

. (org.). Organizing immigrants: the challenge for unions in contemporary

California. Ithaca: Cornell University Press, 2000.

. LA story: immigrant workers and the future of the US labor movement.

New York: Russell Sage Foundation, 2006.

. Millennial movements: Occupy Wall Street and the Dreamers.

Dissent, v. 61, n. 3, pp. 55-59, 2014.

. On gender, labor, and inequality. Urbana: University of Illinois Press, 2016.

A new political generation: millennials and the post-2008 wave of

protest. American Sociological Review, v. 82, pp. 1-31, 2017. 